【論 文】

UDC : 624. 042. $7: 624.04$

\title{
A STOCHASTIC LINEARIZATION TECHNIQUE AND ITS APPLICATION TO RESPONSE ANALYSIS OF NONLINEAR SYSTEMS BASED ON WEIGHTED LEAST-SQUARE MINIMIZATION
}

\author{
by Dr. MASANORI IZUMI*, LI ZAIMING** and Dr. \\ MASAHIKO KIMURA***, Members of A. I. J.
}

\section{Introduction}

We can state that the stochastic linearization method has the greatest potential and widest range of applicability among the extensively developed approaches to the stochastic response analyses of nonlinear systems. For this method some possible techniques have been well developed. Jacobson ${ }^{1)}$ seems to have been the first to use the concept "equivalent work done per cycle assuming harmonic motion" successfully. On the other hand, it is believed that Caughey $^{2)}$ has introduced originally the least-square approximation technique. This approximation technique, which is basically the statistical extension of the deterministic linearization method ${ }^{3)}$, has been generalized by Kobori \& Minai $^{4)}$ to nonstationary excitation, later by Foster ${ }^{5)}$, Iwan \& Yang ${ }^{6)}$ and Takemiya ${ }^{7)}$ to multi-degree-offreedom (MDOF) systems, and further by Kazakov ${ }^{8\rangle}$ to the case of inertial-nonlinear systems. Recently, a more direct and simplified version of Kazakov's linearization technique for MDOF nonlinear systems has been provided by Atalik \& Utku ${ }^{9)}$ and applied by a lot of researchers ${ }^{10)-13)}$. More recently, Spanos ${ }^{14)}$ has extended Atalik \& Utku's linearization to the case of asymmetric nonlinear systems. Since then, the stochastic linearization method has shown higher and higher potential to solve the dynamic problems of nonlinear systems under external random excitations and even under parametric random excitations ${ }^{211}$.

However, it must be noted that for most of the reported studies the existing linearization techniques underestimate the exact statistical moments of the response. As pointed out in References 22) and 23), this poor performance of the stochastic linearization method was mainly due to the existence of a predominant long period component (so-called drift component) in the response. In order to account for the drift component, an additional state variable (so-called hysteresis component) has been introduced in formulating the problems ${ }^{18), 19), 24)}$. Since then, the more accurate response statistics have been obtained by the stochastic linearization method. Nevertheless, the works by the authors and by Schuëller, et al. ${ }^{25)}$ independently suggested that the displacement response predicted by the stochastic linearization method is far less satisfactory than the obtained velocity response for a strong yielding nonlinear system. As a consequence, the authors tried in Reference 15 to raise the grim limitation and presented a modified stochastic linearization, which unfortunately seems to overestimate the exact solution slightly. This paper is intended to develop an improved version of the linearization method for MDOF nonlinear systems with the concept of weighted least-square minimization. The present technique will produce a direct and simple formulation of the linearization. The accuracy will be investigated by some numerical examples (softening or hardening and hysteretic systems). Furthermore, in order to show its universality of application we will apply this method to the so-called piece-wise-linear hysteretic systems as well.

\section{Nonlinear System}

Without loss of generality, consider a symmetric nonlinear vibration system which can be expressed by the

* Professor of Tohoku University, Dr. of Engineering

** Postgraduate Student of Tohoku University

*** Research Associate of Tohoku University, Dr. of Engineering (Manuscript received June 2, 1988) 
equation of motion of the form :

$$
\frac{d X}{d t}=G(X, t)+F(t)
$$

where $\quad X$ is the $n$ dimensional state variable vector.

$G(X, t)$ is the $n$ dimensional vector of single valued odd functions of its arguments $X$ and meanwhile is sufficiently smooth so that the first partial derivatives with respect to $x_{i}, i=1, \cdots \cdots n$ exist.

$F(t)$ is the n dimensional Gaussian white excitation vector with zero mean.

Generally, the nonlinear vibration systems can be divided into softening systems and hardening systems, as illustrated in Fig. 1. It is observed that the distribution of any single argument $x_{i}$ is less peaked for a softening system but more peaked for a hardening system when the normal distribution serves as the standard, as shown in Fig. 2.

\section{Derivation of the Stochastic Linearization Technique}

It was noted earlier that most of the existing linearization techniques underestimate the random responses of nonlinear systems. This limitation can be interpreted easily by the fact that the linearization method relies simply on the Gaussian assumption despite of the existence of the non-normality of the responses. However, it is believed that this limitation may be eased to some extent by applying the weighted least-square minimization technique to the linearization

\subsection{Weighting Functions}

The weighted least-square minimization concept requires that the squared error be multiplied by a weighting function $W(x)$. Here, the most important thing is to choose the weighting function properly. Generally, we can interpret this weighting function $W(x)$ as a relative importance of the value assigned to the object function $f(x)$ at $x$. In particular, for the case of the stochastic linearization the weighting function $W(x)$ can be considered to be in accordance with the difference between the non-Gaussian distribution of the response $x$ in the nonlinear system and the normal distribution of the response in the corresponding linear system. Of course, this difference can not be described precisely but only be assumed qualitatively. Based on the above theoretic consideration of the weighting functions themselves and the observations from numerical simulation studies, the weighting functions for a hardening system and a softening system are supposed to assume

$$
W_{h}(x)=\exp \left\{-\frac{x^{2}}{8 \sigma_{x}^{2}}\right\} \quad \text { for a hardening system }
$$

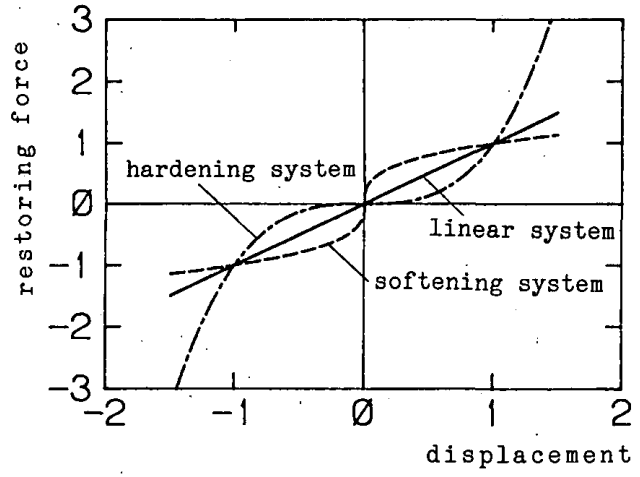

Fig. 1 Hardening system and softening system

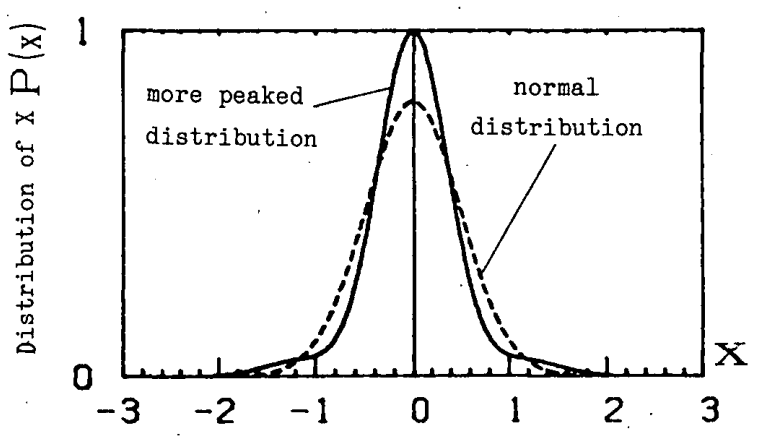

Fig. 2(a) More peaked distribution

$$
W_{s}(x)=\exp \left\{\frac{x^{2}}{32 \sigma_{x}^{2}}\right\}
$$

for a softening system

respectively, where $\sigma_{x}$ means the standard deviation of argument $x$; and subindexes $h$ and $s$ represent "hardening" and "softening", respectively. Clearly, $W_{h}(x)$ has more peakedness but instead $W_{s}$ has less peakedness, as illustrated in Fig. 3. This statement shows accordance with the properties of the hardening system and the softening system mentioned in section 2 .

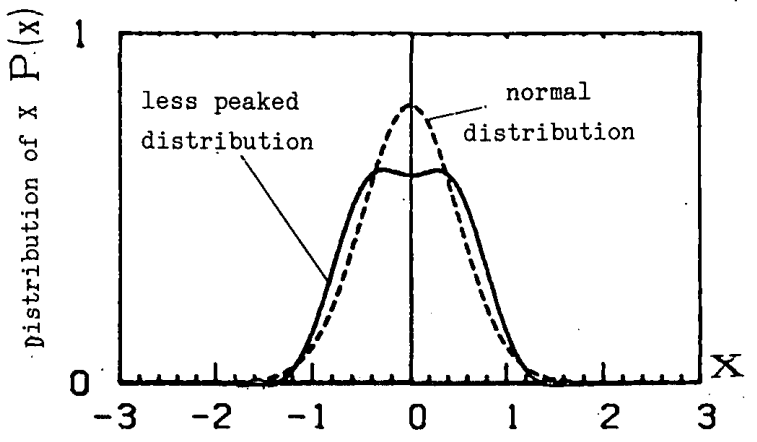

Fig. 2( b ) Less peaked distribution 


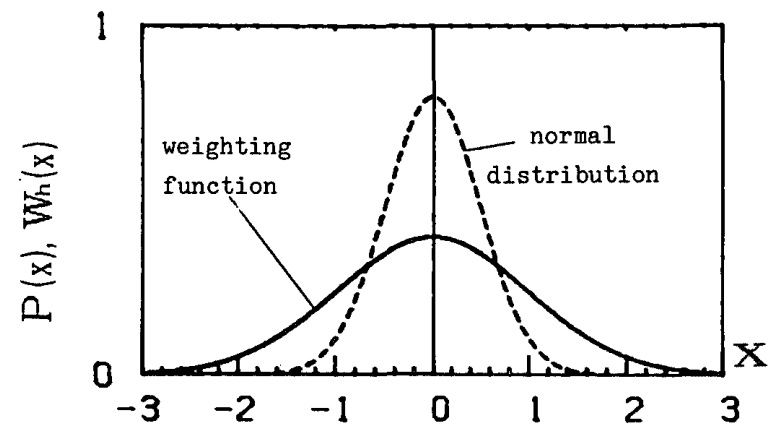

Fig. 3( a) Weighting function for hardening system

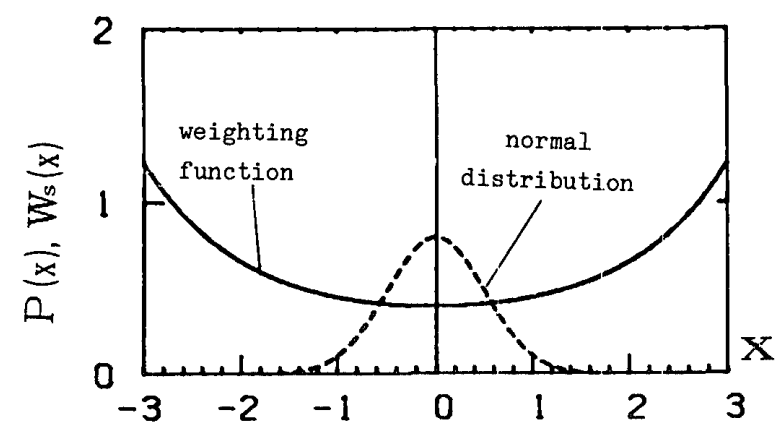

Fig. 3(b ) Weighting function for softening system

The weighting functions described above can be generalized to a multi-dimensional system as follows.

$$
\begin{array}{ll}
W_{h}(X)=\exp \left\{-\frac{1}{8} X^{t} S^{-1} X\right\} & \text { for a multi-dimensional hardening system } \\
W_{s}(X)=\exp \left\{\frac{1}{32} X^{t} S^{-1} X\right\} & \text { for a multi-dimensional softening system }
\end{array}
$$

where $S$ is the covariance matrix of the state variable vector $X$.

It is worth noting that since the weighting functions proposed here take different forms, depending on the system exhibiting either hardening or softening characteristics, they can not be applied without any modification to a nonlinear system which exhibits the characteristics of response transition from hardening to softening or inversely from softening to hardening.

\subsection{Formulation of the Linearization Technique}

Linearize the equation of motion ( 1 ) into

$$
\frac{d X}{d t}=A X+F(t)
$$

where the equivalent coefficient matrix $A$ is to be determined so that the linear system ( 6 ) will produce the most approximate solution to system ( 1 ). In estimating $A$, the difference of the two systems, i.e.

$$
e(X)=G(X, t)-A X
$$

should be committed. Generally, the difference $e(X)$ is a random vector. A logical choice to select $A$ is, therefore, to make the difference as small as possible. Some criteria might be effective to this problern. In this paper, the concept of the weighted least-square minimization will be utilized. This concept requires that the mean squared value of $e(X)$ multiplied by a weighting function $W(X)$ be a minimum, that is

$$
E\left[e^{t}(X) e(X) W(X)\right] \longrightarrow \text { minimum }
$$

where $E[x]$ denotes the expected value of $x$ and the prime $t$ means the transpose. The necessary condition for ( 8 ) to be true is

$$
\left(E\left[e^{i}(X) e(X) W(X)\right]\right), a_{i j}=0 \quad i, j=1, \cdots \cdots, n
$$

Performing the above partial differentiation leads the following set of linear equations

$$
E\left[X X^{t} W(X)\right] A^{\imath}=E\left[X G^{\imath}(X) W(X)\right] \cdots
$$

Then the direct formulation of the linearization can be achieved on the basis of the Gaussian property of the response in the equivalent linear system, that is, the joint Gaussian distribution function

$$
p(X)=B \exp \left\{-\frac{1}{2} X^{t} S^{-1} X\right\}
$$

$$
B=\frac{1}{(2 \pi)^{n / 2}|S|^{1 / 2}}
$$

First consider a multi-dimensional hardening system. Then we have

$$
\begin{aligned}
E\left[X X^{t} W_{h}(X)\right] & =\int_{-\infty}^{\infty}(n) \int_{-\infty}^{\infty} X X^{t} W_{h}(X) p(X) d X^{t}=B \int_{-\infty}^{\infty}(n) \int_{-\infty}^{\infty} X X^{t} \exp \left\{-\frac{5}{8} X^{t} S^{-1} X\right\} d X^{t} \\
& =B \frac{8}{5 \sqrt{5}} \int_{-\infty}^{\infty}(n) \int_{-\infty}^{\infty} X X^{t} \exp \left\{-\frac{1}{2} X^{t} S^{-1} X\right\} d X^{t}=\frac{8}{5 \sqrt{5}} S \quad\left(X \rightarrow 2 \sqrt{\frac{1}{5}} X\right)
\end{aligned}
$$

and

$$
E\left[X G^{t}(X) W_{h}(X)\right]=\int_{-\infty}^{\infty}(n) \int_{-\infty}^{\infty} X G^{t}(X) W_{h}(X) p(X) d X^{\imath}=B \int_{-\infty}^{\infty}(n) \int_{-\infty}^{\infty} X G^{t}(X) \exp \left\{-\frac{5}{8} X^{t} S^{-1} X\right\} d X^{t}
$$




$$
\begin{aligned}
& =B \frac{4}{5} \int_{-\infty}^{\infty}(n) \int_{-\infty}^{\infty} X G^{t}\left(\frac{2}{\sqrt{5}} X\right) \exp \left\{-\frac{1}{2} X^{t} S^{-1} X\right\} d X^{t} \quad\left(X \rightarrow 2 \sqrt{\frac{1}{5}} X\right) \\
& =-S \frac{4}{5} \int_{-\infty}^{\infty}(n) \int_{-\infty}^{\infty} G^{t}\left(\frac{2}{\sqrt{5}} X\right) \nabla p(X) d X^{t} \quad\left(\nabla p(X)=-p S^{-1} X\right) \\
& =S \frac{4}{5} \int_{-\infty}^{\infty}(n) \int_{-\infty}^{\infty} p(X) d G^{t}\left(\frac{2}{\sqrt{5}} X\right)=S \frac{8}{5 \sqrt{5}} \int_{-\infty}^{\infty}(n) \int_{-\infty}^{\infty} p(X) \nabla^{t} G(Y) d X^{t} \quad\left(Y=\frac{2}{\sqrt{5}} X\right) \mid \\
& =\frac{8}{5 \sqrt{5}} S E\left[\left.\nabla^{t} G(Y)\right|_{Y=2 / \sqrt{5} x}\right]
\end{aligned}
$$

where

$$
\nabla^{t}=\left[\frac{\partial}{\partial x_{1}}, \frac{\partial}{\partial x_{2}}, \cdots, \frac{\partial}{\partial x_{n}}\right]
$$

Substituting (13) and (14) into (10) yields

$$
a_{i j}=E\left[\left.\frac{\partial g_{i}}{\partial x_{j}}\right|_{x=2 / \sqrt{5} x}\right] \quad \text { (for a multi-dimensional hardening system) }
$$

Next, derive the formulation for a multi-dimensional softening system. In this case, we should select the weighting function ( 5 ) instead of (4). Similarly, we can show that the direct form of the coefficient matrix $A$ is given by

$$
a_{i j}=E\left[\left.\frac{\partial g_{i}}{\partial x_{j}}\right|_{x=4 / \sqrt{1} 5 x}\right] \quad \text { (for a multi-dimensional softening system) }
$$

As a consequence, it is obvious that the closed form of the coefficients of the equivalent linear system can be obtained directly by application of partial differentiation and expectation to the nonlinear terms involved in the nonlinear system.

It is interesting to compare the present technique with Atalik \& Utku's technique ${ }^{9)}$ which describes that the coefficients of the linear system (6) are expressed by

$$
a_{i j}=E\left[\frac{\partial g_{i}}{\partial x_{j}}\right] \quad \text { (by Atalik \& Utku) }
$$

regardless of a hardening system or a softening system. It should be noted here that the present formulation shows an apparent difference from Atalik \& Utku's technique since in the present technique the difference between the distributions of the responses of the nonlinear system ( 1 ) and the equivalent linear system ( 6 ) has been taken into account.

\section{Examples and Accuracy}

In the preceding section, the direct formulation of the present stochastic linearization has been presented in depth. In order to investigate its accuracy some numerical examples will be shown in this section.

4. 1 hardening system $A$ : nonlinearities inherent in restoring forces

The system is governed by the following equation of motion

$$
\ddot{x}+\beta \dot{x}+\alpha x^{3}=f(t)
$$

where $\beta$ expresses the damping constant, $\alpha$ represents the nonlinear stiffness constant and $f(t)$ is a Gaussian white noise process with

$$
E[f(t)]=0 ; \quad E[f(t) f(t+\tau)]=2 S_{0} \beta \delta(\tau)
$$

The exact stationary mean squared displacement, obtained by the Fokker-Planck equation approach ${ }^{17)}$, is

$$
\sigma_{x e}^{2}=0.6770\left(S_{0} / \alpha\right)^{1 / 2}
$$

where subindex $e$ means "exact". On incorporating (16), the equivalent linear system to (19) can be found to be

$$
\ddot{x}+\beta \dot{x}+k x=f(t)
$$

where

$$
k=E\left[\left.\frac{\partial\left(\alpha x^{3}\right)}{\partial x}\right|_{x=2 / \sqrt{5} x}\right]=3 \alpha \frac{4}{5} \sigma_{x}^{2}=2.4 \alpha \sigma_{x}^{2}
$$

Thus by the standard theory ${ }^{16)}$ of linear vibration systems, the mean squared value of the stationary displacement of 
system (22) is,

$$
\sigma_{x a}^{2}=\frac{S_{0}}{k}
$$

where subindex $a$ means "approximate". Substituting (23) into (24) and solving for the approximate solution yields

$$
\sigma_{x a}^{2}=\left(S_{0} / 2.4 \alpha\right)^{1 / 2}=0.6455\left(S_{0} / \alpha\right)^{1 / 2}
$$

On the other hand, on the basis of Atalik \& Utku's linearization technique the approximate solution has been given to $\mathrm{be}^{9)}$

$$
\sigma_{x a}^{2}=0.5776\left(S_{0} / \alpha\right)^{1 / 2}
$$

Thus the percent errors committed in applying the two techniques can be measured by

$$
\begin{array}{ll}
(0.6770-0.6455) / 0.6770=4.6 \% & \text { (by the present technique) } \\
(0.6770-0.5776) / 0.6770=14.6 \% & \text { (by Atalik \& Utku) } \cdots \ldots \ldots \ldots . . . . .
\end{array}
$$

4. 2 hardening system $B$ : nonlinearities inherent in damping forces

Consider the system described by the governing equations as follows

$$
\begin{aligned}
& \ddot{x}+g(\dot{x}, x)=f(t) \cdots \ldots \ldots \ldots \\
& g(\dot{x}, x)=\beta\left(\dot{x}^{2}+\alpha x^{2}\right) \dot{x}+\alpha x
\end{aligned}
$$

where $\beta$ is the nonlinear damping coefficient, $\alpha$ is the stiffness and $f(t)$ is a Gaussian noise which has the same properties as those given by (20). The exact mean squared values of the responses are, as given in Reference 17

$$
\begin{aligned}
& \sigma_{x e}^{2}=0.5642 \alpha^{-1} S_{0}^{1 / 2} \ldots \\
& \sigma_{x e}^{2}=0.5642 S_{0}^{1 / 2} \ldots \ldots
\end{aligned}
$$

Applying the present linearization technique (16), we can rewrite the system (29) into

$$
\ddot{x}+c \dot{x}+k x=f(t)
$$

where

$$
\begin{aligned}
& c=E\left[\left.\frac{\partial g(\dot{x}, x)}{\partial \dot{x}}\right|_{x=2 / \sqrt{5} x}\right]=3 \beta \frac{4}{5} \sigma_{x}^{2}+\beta \alpha \frac{4}{5} \sigma_{x}^{2} \\
& k=E\left[\left.\frac{\partial g(\dot{x}, x)}{\partial x}\right|_{x=2 / \sqrt{5} x}\right]=2 \beta \alpha \frac{4}{5} \sigma_{x x}^{2}+\alpha \cdots \cdots
\end{aligned}
$$

From the standard theory of linear vibration systems ${ }^{16)}$, we have

$$
\begin{aligned}
& \sigma_{x a}^{2}=\frac{S_{0} \beta}{c k} \\
& \sigma_{x a}^{z}=\frac{S_{0} \beta}{c} \\
& \sigma_{x x a}^{z}=0
\end{aligned}
$$

Substituting (34) and (35) into (36) and (37), yields

$$
\begin{aligned}
& \sigma_{x a}^{2}=0.5590 \alpha^{-1} S_{0}^{1 / 2} \ldots \\
& \sigma_{x a}^{2}=0.5590 S_{0}^{1 / 2} \ldots \ldots
\end{aligned}
$$

On the other hand, Atalik \& Utku has given another approximate solution as follows

$$
\begin{aligned}
& \sigma_{x a}^{2}=0.5 \alpha^{-1} S_{0}^{1 / 2} \\
& \sigma_{x a}^{2}=0.5 S_{0}^{1 / 2} \ldots \ldots
\end{aligned}
$$

Similarly, the percent error can be calculated by

$$
\begin{array}{ll}
(0.5642-0.559) / 0.5642=0.9 \% & \text { (by the present technique) } \\
(0.5642-0.500) / 0.5642=11.4 \% & \text { (by Atalik \& Utku) } \ldots . . . . . .
\end{array}
$$

4.3 softening system $A$ : nonlinearities inherent in restoring forces

The nonlinear softening oscillator is described by the following differential equation

$\ddot{x}+\beta \dot{x}+\alpha x^{1 / 3}=f(t)$

where $\beta, \alpha$ are the damping constant and stiffness constant, respectively, and $f(t)$ is a Gaussian white noise with the properties given by $(20)$. This system is utilized here only for the sake of the accuracy discussion. Define the equivalent linear system as

$$
\ddot{x}+\beta \dot{x}+k x=f(t)
$$

where $\mathbf{k}$ can be expressed by incorporating (17) as 


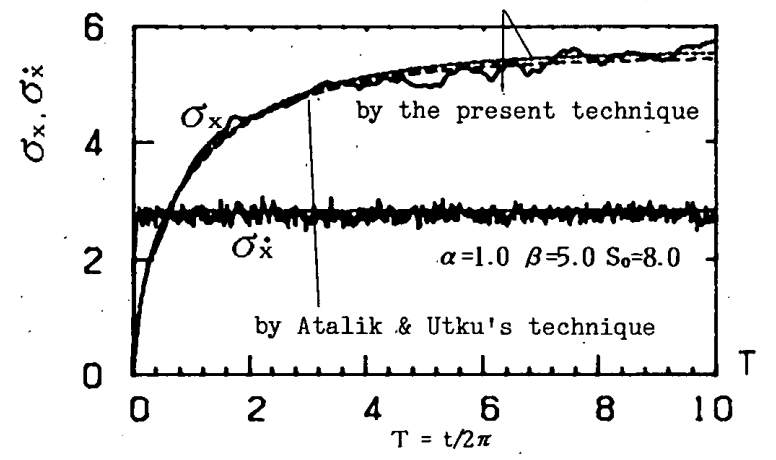

Fig. 4( a ) RMS history for softening system A

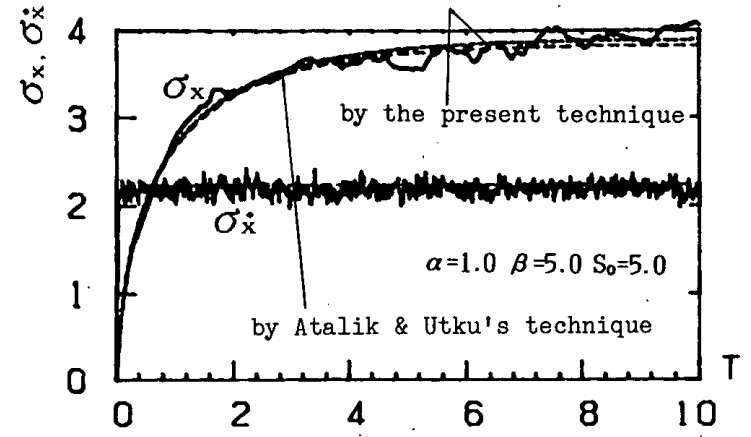

Fig. 4(b) RMS history for hardening system A

$$
k=E\left[\left.\frac{\partial\left(\alpha x^{1 / 3}\right)}{\partial x}\right|_{x=2 / \sqrt{15} x}\right]=\frac{1}{3} \alpha \sqrt[3]{\frac{15}{16}} E\left[x^{-2 / 3}\right]=0.81 \alpha \sigma_{x}^{-2 / 3}
$$

On the other hand, imposing Atalik \& Utku's linearization technique also gives an equivalent linear system with the coefficient expressed by

$$
k=E\left[\frac{\partial\left(\alpha x^{1 / 3}\right)}{\partial x}\right]=\frac{1}{3} \alpha E\left[x^{-2 / 3}\right]=0.83 \alpha \sigma_{x}^{-2 / 3}
$$

Some analytical results by the above two techniques are plotted and compared with the Monte-Carlo simulation solutions in Fig. 4. From Fig. 4, it is obvious that both the present technique and Atalik \& Utku's technique have produced rather satisfactory solutions to the response. In addition, it should be noted that this is true even when the system is excited at strong nonlinear response level.

4.4 softening system B : hysteretic nonlinearities by Y.K. Wen

The system considered here is a sofening hysteretic $\mathrm{Y} . \mathrm{K}$. Wen model ${ }^{18}$, as shown in Fig. 5. The nondimensional governing equation of motion is described by

$$
\ddot{x}+2 h \dot{x}+\alpha x+(1-\alpha) z=f(t)
$$

where $h$ and $\alpha$ are the damping coefficient and the post-to-preyield stiffness ratio, respectively; $f(t)$ is a Gaussian white noise with

$$
E[f(t)]=0 ; \quad E[f(t) f(t+\tau)]=S_{0} \delta(\tau)
$$

and $z$ is the so-called hysteresis and related to $x$ through the following first order differential equation

$$
\dot{z}=g_{z}(z, \dot{x}) ; \quad g_{z}(z, \dot{x})=-\gamma|\dot{x}| z|z|^{n-1}-\beta \dot{x}|z|^{n}+\zeta \dot{x}
$$

In the above expression $\gamma, \beta, \zeta$ and $n$ are parameters. $\gamma$ and $\beta$ control the shape of the hysteresis loop, $\zeta$ the restoring force, and $n$ the smoothness of the hysteresis. In this paper, the imposed parameters are $n=1, \zeta=1$. 0 , and $\beta=\gamma=0.5$.

Linearize (51) into

$$
\dot{z}=c \dot{x}+k z
$$

Following Y.K. Wen ${ }^{10)}$, the linear coefficients $\mathrm{c}$ and $\mathrm{k}$ are given by

$$
c=1-\frac{1}{\sqrt{2} \pi}\left\{\frac{E[\dot{x} z]}{\sigma_{\dot{x}}^{\dot{x}}}+\sigma_{z}\right\}
$$

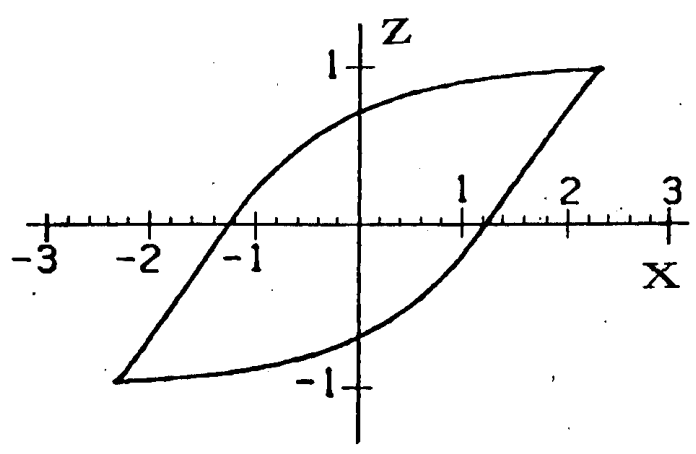

Fig. 5 Y.K. Wen hysteretic model

$$
k=-\frac{1}{\sqrt{2} \pi}\left\{\sigma_{\dot{x}}+\frac{E[\dot{x} \dot{z}]}{\sigma_{z}}\right\}
$$

On the other hand, incorporating the present technique (17) yields the linear coefficients as

$$
\begin{aligned}
& c=1-\frac{4}{\sqrt{30} \pi}\left\{\frac{E[\dot{x} z]}{\sigma_{\dot{x}}}+\sigma_{z}\right\} \\
& k=-\frac{4}{\sqrt{30} \pi}\left\{\sigma_{\dot{x}}+\frac{E[\dot{x} z]}{\sigma_{z}}\right\} .
\end{aligned}
$$

On the above two techniques, some case studies are performed and the analytical results are compared with 


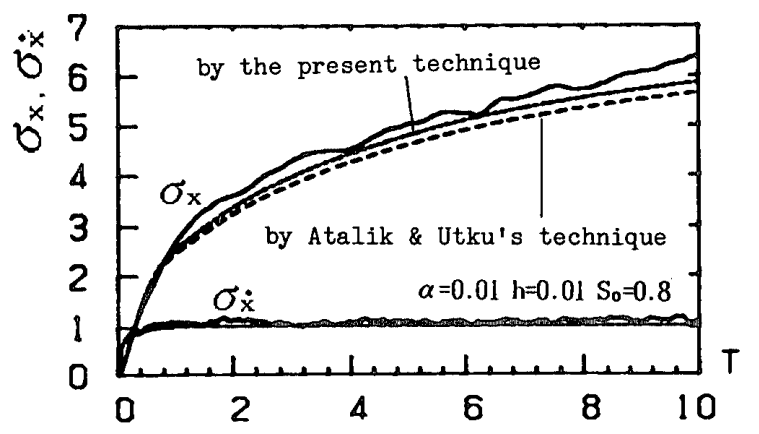

Fig. 6(a) RMS history for softening system B

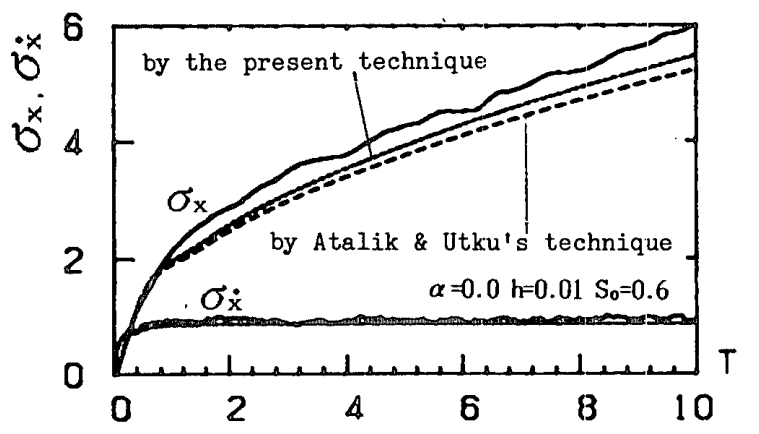

Fig. 6(b) RMS history for hardening system B

the Monte-Carlo simulation solutions in Fig. 6. As a result, the present technique has produced a better solution than Atalik \& Utku's technique.

\section{Application to piece-wise-linear hysteretic systems}

The term "piece-wise-linear hysteretic systems" or p. w. l. hysteretic systems for short refers to nonlinear models in which the hysteretic characteristics consist of piece-wise-linear behaviour. In such models, the expressions of the governing equations are not smooth and, therefore, the first derivatives of the expressions with respect to the arguments do not exist. It has been pointed out ${ }^{15)}$ that this non-smoothness prevents the application of the linearization method. As a consequence, the authors have developed a useful approach ${ }^{19)}$ to smooth the general differential expressions of the p.w.1. hysteretic systems so that it becomes possible to apply the stochastic linearization method. Later the smoothing approach has been generalized to MDOF p. w. l. hysteretic systems ${ }^{20)}$. In this section, based on the smoothing approach, we will apply the present improved stochastic linearization technique to the p.w. l. hysteretic systems.

The nondimensional equations of motion of the p.w.l. hysteretic systems can be expressed generally by ${ }^{19)}$

$$
\begin{aligned}
& \ddot{x}+2 h \dot{x}+\alpha x+(1-\alpha) z=f(t) \\
& \dot{z}=k \dot{x}[1-U(\dot{x}) U(z-1)-U(-\dot{x}) U(-z-1)]=f(\dot{x}, z)
\end{aligned}
$$

Where $\alpha$ is the post-to-preyield stiffness ratio, $k$ is the hysteresis coefficient which depends on the characteristics of the hysteretic systems; and $U$ is the $U$-step function defined by

$$
U(x)=\left(\begin{array}{ll}
1 & x \geqq 0 \\
0 & x<0
\end{array}\right.
$$

Clearly, the differential expression of the hysteresis (58) is not smooth and, therefore, the application of the linearization is unavailable. The approach developed in Reference 19 is to smooth the differential expression (58) in an equivalent probabilistic sense through approximating the U-step functions as

$$
\begin{aligned}
& U(\dot{x})=\frac{1}{2}(1+\operatorname{sgn} \dot{x})=\left(\begin{array}{rl}
1 & \dot{x}>0 \\
0.5 & \dot{x}=0 \ldots \ldots \ldots \ldots \ldots \ldots \ldots \ldots \ldots \ldots \ldots \ldots \ldots \ldots \ldots \ldots \\
0 & \dot{x}<0
\end{array}\right. \\
& U(z-1)=\frac{1}{2}|z|^{n}(1+\operatorname{sgn} z)
\end{aligned}
$$

As a result, the smooth differential expression has been gained as

$$
\dot{z}=\bar{k}\left[\dot{x}-0.5|z|^{n} \dot{x}-0.5|\dot{x}| z|z|^{n-1}\right] \quad \text { for a positive } n \text {. }
$$

where $\bar{k}$ is the smooth hysteresis coefficient which can be derived by the same approximations from $k$. Parameter $n$ is to control the smoothness of $U(z-1)$ and meanwhile the transition of the hysteresis, as illustrated in Fig. 7. Theoretically, when $n \rightarrow \infty$, the smooth hysteretic systems become the p.w. 1. hysteretic systems. It should be noted that $n$ be so chosen that it may produce the same probabilistic information and at the same time give the smoothness of the differential expression.

For example, consider the bilinear system subjected to a Gaussian white noise excitation. In this case, the appropriate choice of $n$ has been shown ${ }^{19)}$ to be 3 . Then the expression of the hysteresis is described by

$$
\dot{z}=\dot{x}-0.5|z|^{3} \dot{x}-0.5|\dot{x}| z^{3}
$$


Thus the hysteresis loop becomes rather smooth, as shown in Fig. 8. Incorporating the present technique (17) yields the equivalent linear system as

$$
\begin{aligned}
& \ddot{x}+2 h \dot{x}+\alpha x+(1-\alpha) z=f(t) \\
& \dot{z}=b \dot{x}+c z \ldots \ldots \ldots \ldots \ldots \ldots \ldots \ldots \ldots \ldots \ldots \ldots \ldots
\end{aligned}
$$

where

$$
\begin{aligned}
& b=1-1.1\left\{\frac{1}{\sqrt{2} \pi} \sigma_{z}^{3} \rho_{\dot{x} z}\left(3-\rho_{x z}^{2}\right)+\sqrt{\frac{2}{\pi}} \sigma_{z}^{3}\right\} \ldots \ldots \ldots \\
& c=-1.1\left\{\frac{3}{\sqrt{2} \pi} \sigma_{z}^{2} \sigma_{\dot{x}}\left(1+\rho_{\dot{x} z}^{2}\right)+3 \sqrt{\frac{2}{\pi}} \rho_{\dot{x} z} \sigma_{z}^{2} \sigma_{\dot{x}}\right\} \\
& \rho_{\dot{x} z}=\frac{E[\dot{x} z]}{\sigma_{\dot{x}} \sigma_{x}} \ldots \ldots \ldots \ldots \ldots \ldots \ldots \ldots \ldots \ldots \ldots \ldots \ldots \ldots \ldots \ldots \ldots \ldots \ldots \ldots \ldots \ldots \ldots \ldots \ldots \ldots
\end{aligned}
$$

As a result, the covariance matrix of the response can be solved on the basis of the standard theory of linear vibration systems. Some numerical analyses are performed and the results are compared with the Monte-Carlo simulation solutions, as shown in Fig. 9. Fig. 9 shows that the present technique produces rather dependable results for strong nonlinearities as well as for weak nonlinearities. Also shown by the broken lines are the results based on Atalik \& Utku's linearization technique. From the results in Fig.9, it may be concluded that the present linearization technique yields better approximate solutions for response statistics than that by Atalik \& Utku.

\section{Conclusions}

On the basis of the weighted least-square minimization concept, an improved stochastic linearization technique has been developed. In this technique, the difference between the distributions of the responses of the nonlinear system and the corresponding equivalent linear system has been taken into account in the form of the weighting functions. It has been shown that the exact closed forms of the coefficients of the equivalent linear system can be obtained simply by direct application of partial differentiation and expectation to the nonlinear terms.

Through applying the present technique to a certain number of examples, the accuracy has been investigated. As a result, it has been observed that this technique produces better solutions than the existing linearization method.

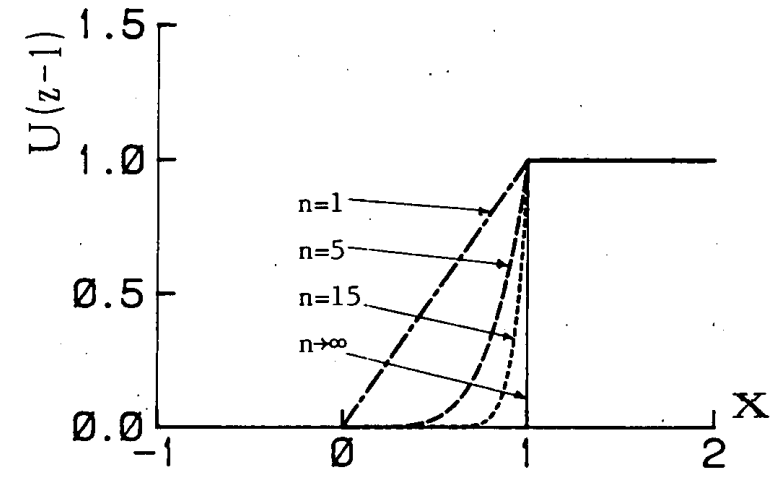

Fig. 7(a) Smoothness of $U(z-1)$

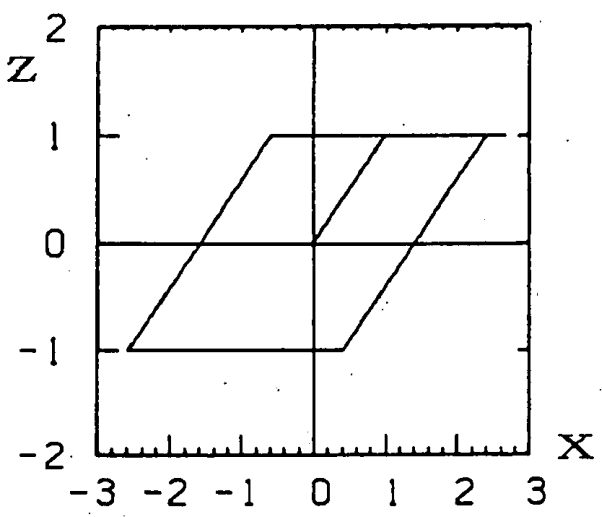

Fig. 8(a) p.w. l. bilinear model

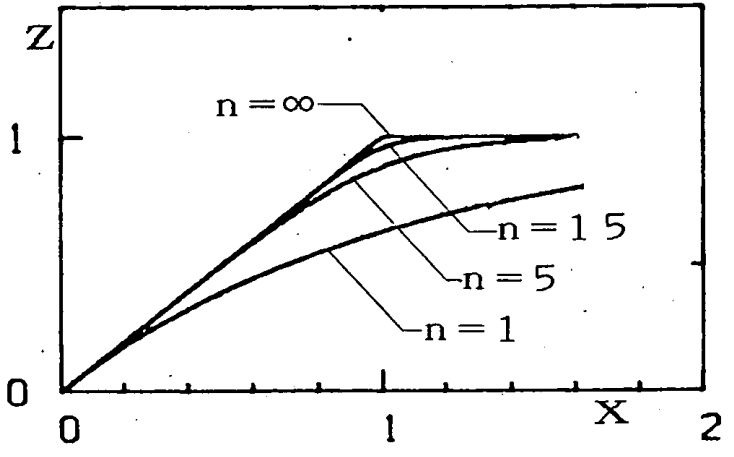

Fig. 7(b) Smoothness of transition

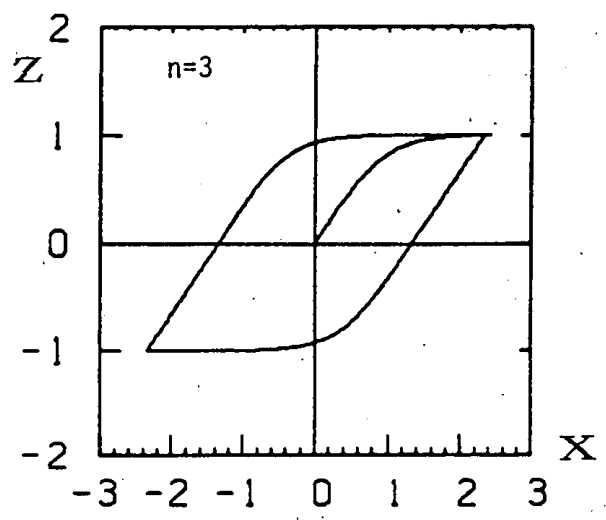

Fig. 8(b) Smooth bilinear model 


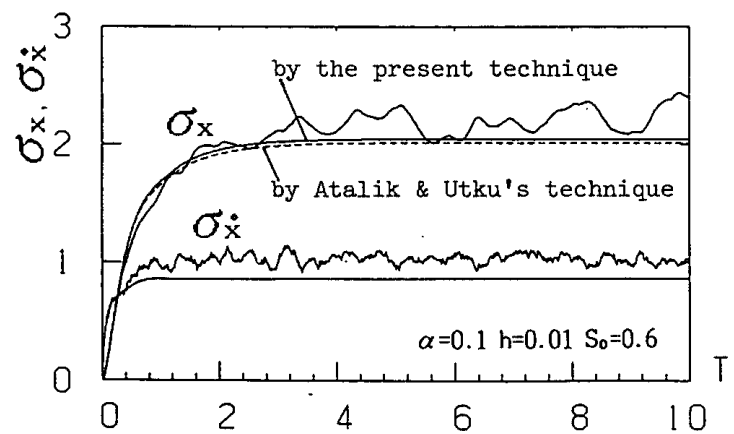

Fig. 9( a ) RMS history for bilinear system

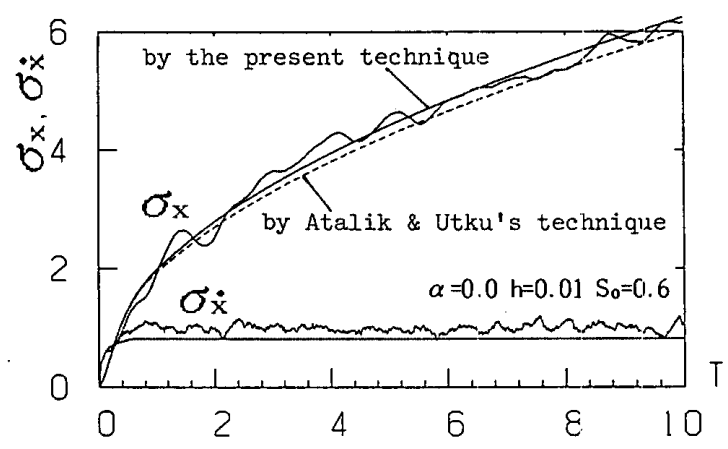

Fig. 9(b) RMS history for bilinear system

Furthermore, this technique has been also applied to the piece-wise-linear hysteretic systems. In this case, we have to smooth the differential expression of the hysteresis before we can apply the present technique. Through performing some numerical studies, it has been shown that the accuracy of the present technique is rather dependable even for strong nonlinearities.

Finally, the present technique can be successfully applied to multi-degree-of freedom nonlinear systems under white noise excitations or subjected to more complex stochastic excitation noises obtained by the filtering of a white noise.

\section{References}

1) Jacobson, L.S., "Steady forced vibration as influenced by damping", Trans Amer. Soc. Mech. Engrs 52, APIM-5-2-15, 1930.

2) Caughey, T.K., “Equivalent linearization techniques", J. Acoust. Soc. Amer. Vol. 35, pp. 1706-1711, 1963.

3) Krylov, N. and Bogoliubov, N., Introduction to Nonlinear Mechanics, Princeton University Press, Princeton, N. J. , 1943.

4) Kobori, T. and Minai, R., "Linearization technique for evaluating the elasto-plastic response of a structural system to non-stationary random excitations”, Bulletin of the Disaster Prevention Research Institute, Kyoto Univ., Vol. 10, Part A, pp. 1-26, March, 1967 (in Japanese)

5) Foster, E. T., “Semilinear random vibrations in discrete systems”, J. Appl. Mech. Vol. 35, pp. 560-564, 1968.

6) Iwan, W. D. and Yang, I., "Application of statistical linearization techniques to nonlinear multi-degree-of-freedom systems", J. Appl. Mech. Vol. 39, pp. 545-550, 1972.

7) Takemiya, H., "Stochastic seismic response analysis of a multi-degree-of-freedom hysteretic structures", Proceedings of the Japan Society of Civil Engneers, Vol.245, pp.17-26, 1976. (in Japanese).

8) Kazakov, I.E., "Generalization of the method of statistical linearization to multi-dimensional systems", Autornation and Remoto Contorl, Vol.26, pp.1201-1206, 1965.

9) Atalik, T.S. and Utku, S., "Stochastic linearization of multi-degree-of-freedom non-linear systems", Earthquake Engineering and Structural Dynamics, Vol.4, pp.411-420, 1976.

10) Wen, Y.K., "Equivalent linearization for hysteretic systems under random excitations”, J. Appl. Mech., ASME, Vol.47, pp. 150-154, 1980.

11) Park, Y.J., Wen, Y.K. and Ang, A. H-S., "Random vibration of hysteretic systems under bi-directional ground motions", Earthquake Engineering and Structural Dynamics, Vol. 14, pp. 543-557, 1986.

12) Asano, K. and Iwan, W. D., "An alternative approach to the random response of bilinear hysteretic systems", Earthquake Engineering and Structural Dynamics, Vol. 12, pp. 229-236, 1984.

13) Constantinou, M.C. and Tadjbakhsh, I.G., "Hysteretic dampers in base isolation : random approach", J. Structural Engineering, Vol.111, No.4, ASCE, April, pp.705-721, 1985.

14) Spanos, T. D., "Formulation of stochastic linearization for symmetric or asymmetric M. D. O.F. nonlinear systems", J. Appl. Mech., Vol.47, March, pp. 209-211, 1980.

15) Izumi, M., Li Zaiming, Katukura, H., and Kishimoto, K, "A modified stochastic linearization technique to random response analysis of nonlinear structural model”, J. of Structural Engineering, Vol.34 B, AIJ, pp.59-72, March, 1988.

16) Lin, Y.K., Probabilistic Theory of Structural Dynamics, McGraw-Hill, New York, 1967.

17) Caughey, T. K. , "Derivation and application of Fokker-Planck equation to discrete dynamic systems subjected to white noise excitation", J. Acoust. Soc. Amer., Vol.35, pp.1683-1692, 1963.

18) Wen, Y.K., "Method for random vibration of hysteretic systems", J. Engineering Mechanics, Vol. 102, No. EM 2, ASCE, pp. 249-263, April, 1976. 
19) Izumi, M., Li Zaiming and Katukura, H., “Approach to stochastic response analysis of piece-wise-linear hysteretic structural systems : for bilinear model", Trans. of A.I. J., No.390; pp. 59-69, August, 1988.

20) Izumi, M., Li Zaiming, Katukura, H., Kimura, M. and Kishimoto, K., "Stochastic response analysis of MDOF piece-wise-linear hysteretic structures under seismic excitation", Summary of Technical Papers of Annual Meeting, A. I. J. , Structures I, pp. 249-250, October, 1988 (in Japanese).

21) Lin, Y.K., et al., "Exact and Approximate Solutions for Response of Nonlinear System under Parametric and External White Noise Excitations", Nonlinear Stochastic Dynamic Engineering Systems, IUTAM Symposium, Innsbruck, Austria, pp. 323-334, 1987.

22) Izumi, M. and Li Zaiming, "On Drift Response in Elasto-Plastic Hysteretic System Subjected to White Noise Excitation", Proceedings of the 7 th Japan Earthquake Engineering Symposium, Tokyo, Japan, pp.1465-1470, December, 1986.

23) Iwan, W.D. and Pararizos, L.G., "The Stochastic Response of Strongly Yielding Systems-A New Look at An Old Problem", Stochastic Approaches in Earthquake Engineering, U.S.-Japan Jöint Seminar, Boca, Raton, Florida, USA, pp. 101-117, May 6-7, 1987.

24) Kobori, et al., "Stochastic Linearization Techniques of Hysteretic Structures to Earthquake Excitations", Bull. Disas. Prev. Res. Inst., Kyoto Univ., Vol.23, 1973.

25) Pradlwater, H. J. and Schuëller, G. I., “Accuracy and Limitation of the Method of Equivalent Linearization for Hysteretic Multi-Storey Structures”, Nonlinear Stochastic Dynamic Engineering Systems, IUTAM Symposium, Innsbruck, Austria, pp. 1-21, 1987. 


\section{非線形システムの不規則応答解析における重み付き最小二乗化による 等価線形化法およびその応用（梗概）}

\section{1. 序 論}

等価線形化法は，非線形システムの不規則応答解析手 法の中でも，可能性，応用性の点において極めて有力な 手法である。この手法は，多くの研究者によって発展さ せられてきたが(1) ${ }^{(1)}$, 特に Atalik \& Utku の研究(9)によ り大きな発展が見られた年〜14)。筆者らは, Atalik \& Utku の等価線形化法を適用する上での制約を緩和すべ く，等価線形化法の修正を試みてきたが5)，一部にやや 過大評価する傾向がみられた。そこで，本論文は等価線 形システムを重み付き最小二乗化の規範を用いて導出す ることにより，さらに精度の高い等価線形化法の実現を 目的とする。さらにその応用についても述べる。

\section{2. 非線形システム}

ここで，一般性を失わずに（1）式で表現されるよう な対称非線形振動システムを考えることができる。一般 に非線形振動システムは，スケルトンカーブにより硬化 型と軟化型に分けることができる（図一1）。この硬化型 システムと軟化型システムにおける応答の分布は，正規 分布を基準としたとき，それぞれ more peaked と less peakedになる(図一2)。

\section{3. 重み付き最小二乗化による等価線形化法}

\section{1 重み関数}

重み付き最小二乗化の規範を用いる時は，重み関数を 適切に選択することが最も重要であるが，これを一般的 に決定する方法はまだ確立されていない。非線形システ ムの等価線形化法の問題においては，この重み関数を非 線形システムの応答分布が正規分布から外れることに関 連させて定めることが合理的である。この考えと数値解 析結果に基づき, 非線形システムが硬化型か軟化型かに よって，重み関数をそれぞれ（2）式（3）式のよう に設定する（図一-3）。さらに，これらは（4）式と（5) 式のように多次元システムに拡張することができる。

\section{2 手法の誘導}

振動方程式（1）を（6）式のような等価線形システ

$*$ 東北大学 教授 $\cdot$ 工博

***東北大学 大学院生・工修

**** 東北大学 助手. 工博 (略和 63 年 6 月 2 日原稿受理)

$\begin{array}{lllll}\text { 正会員 } & \text { 和 } & \text { 泉 } & \text { 正 } & \text { 哲* } \\ \text { 正会員 } & \text { 李 } & & \text { 再 } & \text { 明** } \\ \text { 正会員 } & \text { 木 } & \text { 村 } & \text { 正 } & \text { 彦*** }\end{array}$

ムに書き換える。ただし，その誤差を（7）式で評価す る。ここで，重み付き最小二乗化の規範により（8）式 が得られる。(8) 式が満足すべき必要条件として（9) 式が成立する。この規範によれば、等価線形システム 式の係数マトリクス $A$ は, 非線形システムが硬化型か 軟化型によってそれぞれ，(16)，(17）式のごとく決定 され，等価線形システムの係数マトリクス $A$ は，非線 形システムの非線形項に偏微分と期待値の操作を直接行 うことにより求めることができる。特に，本等価線形化 法による係数（16)，(17）式と Atalik \& Utkuによる係 数（18）式の違いに注目されたい。

\section{4. 解析例および精度の検討}

4.1 硬化型システムAについて

このシステムは，(19）式で表現される。ただし，入 力 $f(t)$ は $(20)$ 式を満足する Gaussian ホワイトノイ ズである。このシステムの定常二乗変位応答の厳密解は (21) 式で与えられる ${ }^{16)}$ が, 本解析手法と Atalik \& Utku の手法を適用した近似解はそれぞれ（25）と（26） 式となる。この場合の厳密解に対する誤差はそれぞれ $4.6 \%$ ((27) 式), $14.6 \%$ ((28) 式) となり, 本解析 手法を適用した場合の誤差は Atalik \& Utkuに比べ, 大幅に減少しており,精度が向上していることがわかる。

4.2 硬化型システムBについて

(29)，(30）式で表現される非線形システムについて 考える。この時, 定常二乗変位および定常二剰速度応答

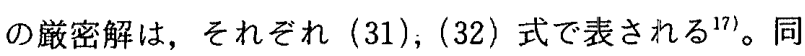
様に, 本解析手法亡 Atalik \& Utku の手法による近似 解は，それぞれ (39)，(40) 式と (41)，(42）式で表現 される。したがって，それぞれの誤差は (43)，(44）式 で評価され，本解析手法による誤差はAtalik \& Utku の手法の $11.4 \%$ に対し $0.9 \%$ と大幅に減少しているこ とがわかる。

4.3 軟化型システムAについて

このシステムは (45) 式で与えられる。いくつかのケー スについて調べたところ, 本解析手法は Atalik \& Utku の手法と同様な高い精度を有することが示された（図一 4)。

4.4 軟化型システムBについて 
ここで考えているシステムは，図一 5 に示すような Y.K. Wen モデルであり，(49) 式により表現される ${ }^{18)}$ 。 (49) 式において, $f(t)$ は $(50)$ 式を満足する Gaussianホワイトノイズであり， $z$ は $(51)$ 式で表される 履歴成分である。同様に，ケーススタディを行った結果， 本解析手法は Atalik \& Utku の手法に比べてより高い 精度を有することが確認された。

5. piece-wise-linear 履歴システムへの応用について piece-wise-linear 履歴システムとは, 区分的に線形特 性を持ち, 弾性領域から塑性領域への応答遷移が滑らか でない履歴特性を持つモデルを指す（以後 p.w.1. 履歴 システムと呼ぶことにする)。 p.w.1. 履歴システムの定 式化は, 多くの研究者によって検討されてきたが, 著者 らは，これをやや違った形で表現し，一般式にまとめて (る ${ }^{19)}$ 。履歴システムにおける無次元振動方程式は (57) ，(58）式によって表現される。ここに $U(x)$ は，U ステップ関数であり，(59) 式により定義される。明ら かに，履歴の表現式（58）は，(59）式で定義される $U$-ステップ関数を含み不連続な特性を有する。この不 連続性は，等価線形化法の適用を困難にする原因である ことが指摘されている ${ }^{15)}$ 。著者らは，応答の確率情報が 等価で，しかも，等価線形化法が適用できる程度に滑ら かな，等価履歴システムを提案し ${ }^{19)}$ ，さらに多質点型非 線形システムに拡張した ${ }^{20)}$ 。その手法は，U-ステップ 関数を $(60)$ と（61）式で近似することにより，すなわ ちU-ステップ関数をスムージングすることにより，等 価履歴システム $(62)$ 式を提案するものである。ここに $n$ は, $U$-ステップ関数 $U(z-1)$ の滑らかさを支配す ると共に，応答の遷移もコントロールするパラメータで ある（図一7）。理論的に $n \rightarrow \infty$ のとき，等価履歴シス
テムは元の p.w.1. 履歴システムと一致する。 $n$ は, 元 の p.w.1. 履歴システムとほぼ同じ履歴エネルギーを持 ち，しかも，等価線形化手法が適用しやすいようにでき るだけ小さくする。という規準で設定するのが合理的で ある。

具体的な例として,バイリニアモデルについて考える。 このモデルにおける $n$ は· 3 と設定されている ${ }^{19)}$ 。その 結果として，履歴は（63）式により表現され，図一7に 示すようにかなり滑らかになり，この系に等価線形化法 を適用することが可能となる。同様に，ケーススタディ を行った結果, piece-wise-linear 履歴システムにおいて も本解析手法による精度は高いことが示された。

\section{6. 結 論}

本論文は，重み付き最小二乗化の規範に基づいて，よ り高い精度を有する等価線形化法の実現とその応用につ いて展開したものである。本等価線形化法の特徴は，非 線形システムの応答が正規分布から外れることが重み関 数として考慮されていることと，等価線形システムの係 数マトリクス $A$ が非線形システムの非線形項に偏微分 と期待值の操作を直接行うことにより容易に求められる ことにある。

いくつかの解析例をとおして，本等価線形化法は，従 来の手法を上回る精度を有することが確認された。

さらに, 本解析手法の piece-wise-linear 履歴システ ムへの適用について述べた。この際，スムージング法に よる等価履歴への置換が必要である。バイリニアモデル を例に，モンテカルロ法による数値解析結果と比較した ところ, 本等価線形化法は非線形性の大きな piecewise-linear 复歴システムにおいても高い精度を持つこ とが明らかになった。 